\title{
REGISTRY OF HOSPITAL DAS CLÍNICAS OF THE UNIVERSITY OF SÃO PAULO MEDICAL SCHOOL: FIRST OFFICIAL SOLID ORGAN AND TISSUE TRANSPLANTATION REPORT - 2008
}

\author{
Estela Azeka, José Otavio Costa Auler Júnior, Paulo Manuel Pego Fernandes, \\ Willian Carlos Nahas, Alfredo Inácio Fiorelli, Uenis Tannuri, Lílian Maria \\ Cristofani, Marcelo Tadeu Caiero, Frederico Luiz Dulley, André de Oliveira \\ Paggiaro, Telesforo Bacchella
}

doi: $10.1590 / \mathbf{S 1 8 0 7 - 5 9 3 2 2 0 0 9 0 0 0 2 0 0 0 1 0}$

\begin{abstract}
Azeka E, Auler Jr JOC, Fernandes PMP, Nahas WC, Fiorelli AI, Tannuri U, Cristofani LM, Caiero MT, Dulley FL, Paggiaro AO, Bacchella T. Registry of Hospital das Clínicas of the University of São Paulo Medical School: first official solid organ and tissue transplantation report - 2008. Clinics. 2009;64:127-34.
\end{abstract}

OBJECTIVE: The aim of this study was to report a single center experience of organ and tissue transplantation INTRODUCTION: This is the first report of organ and tissue transplantation at the Hospital das Clínicas of the University of Sao Paulo Medical School.

METHODS: We collected data from each type of organ transplantation from 2002 to 2007 . The data collected were patient characteristics and actuarial survival Kaplan-Meier curves at 30 days, one year, and five years

RESULTS: There were a total of 3,321 transplants at our institution and the 5-year survival curve ranged from 53\% to $88 \%$.

CONCLUSION: This report shows that solid organ and tissue transplants are feasible within the institution and allow us to expect that the quality of transplantation will improve in the future.

KEYWORDS: Transplantation; Registry; Solid organ; Tissue.

\section{INTRODUCTION}

Transplantation has been an option for patients with end-stage organ disease and can provide a chance for survival. Our institution is one of the largest medical school hospitals in this country, with a relatively significant activity in complex procedures and transplants..$^{-5}$ The aim of this registry was to report the experience of transplantation at our institution for the last five years. It represents a unique data repository in an effort to help patients with untreated disease with conventional therapy.

Solid Organ and tissue Transplantation Committee of the University of São Paulo Medical School, São Paulo/SP, Brazil

Corresponding author: Dr. Estela Azeka - Diretoria Clínica do Hospital das Clínicas, Faculdade de Medicina, Universidade de São Paulo, São Paulo/ SP, Brazil

Email: diretoria.clinica@hcnet.usp.br

Tel.: 5511 3063-3032

Received for publication on October 16, 2008

Accepted for publication on October 29, 2008

\section{PATIENTS AND METHODS}

Data were collected from each organ and tissue transplantation carried out from 2002 to 2007. The following parameters were studied: the number of transplants, age of recipient, indications for transplantation, maintenance immunosuppression protocols [calcineurin inhibitor (cyclosporine or tacrolimus), cytostatic drugs, and the use of steroids], major complications, causes of death, and the survival curve for each organ and tissue.

For statistical analysis, all data were reported as median, minimum, and maximum values. Survival rates were calculated using the Kaplan-Meier method. All analyses were performed with SPSS statistical software, version 10.0 (SPSS Inc., Chicago, IL, USA).

\section{RESULTS}

The registry of transplantation at the Hospital das 
Clínicas of the University of Sao Paulo Medical School covers organ and tissue transplants from 2002 through 2007.

The total number of recipients who received transplants was 3,321 (Table 1). There were 1,288 and 2,033 transplants of solid organs and tissue, respectively (Figure 1). The age of the recipients ranged from 0.6 to 90 years (Table 2). The distribution of the solid organ transplants per year ranged from 187 to 265 transplants (Figure 1).

\section{Pediatric heart transplantation}

Thirty-two pediatric patients aged from 0.9 years to 13.8 years (median: 6.0 years) were submitted to heart

Table 1 - Number of transplant recipients at Hospital das Clínicas of the University of São Paulo Medical School (2002-2007)

\begin{tabular}{lc}
\hline Organ & $\mathrm{N}$ \\
\hline Heart & 32 \\
- Pediatric & 109 \\
- Adult & \\
Liver & 135 \\
- Pediatric & 204 \\
- Adult & 37 \\
Pancreas-kidney & 56 \\
Lung & 715 \\
Kidney & 665 \\
- Adult & 50 \\
- Pediatric & 1288 \\
\hline Total & $\mathrm{N}$ \\
\hline Tissue & \\
\hline Bone marrow & 57 \\
- Pediatric & 728 \\
- Adult & 81 \\
Skin & 1167 \\
Bone & 2033 \\
\hline Total &
\end{tabular}

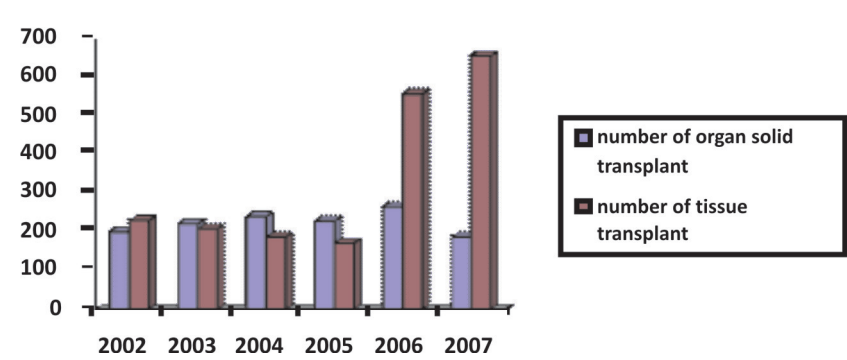

Figure 1 - The total number of solid organ and tissue transplants per year (2002 to 2007)
Table 2 - Age distribution (years) of transplant recipients

\begin{tabular}{lccc}
\hline Organ & Median & $\min$ & $\max$ \\
\hline $\begin{array}{l}\text { Heart } \\
\quad \text { Pediatric }\end{array}$ & 6 & 0.9 & 13.8 \\
$\quad$ Adult & 47 & 11 & 69 \\
Liver & & & \\
$\quad$ Pediatric & 4 & 0.6 & 16 \\
$\quad$ Adult & 47 & 14 & 70 \\
Pancreas-kidney & 36 & 25 & 41 \\
Lung & 47 & 6 & 67 \\
Kidney & & & \\
$\quad$ Pediatric & 13 & 3 & 17 \\
$\quad$ Adult & 45 & 18 & 78 \\
\hline
\end{tabular}

transplantation. The indications of heart transplantation were dilated cardiomyopathy in 25 patients $(78 \%)$ and congenital heart disease in seven patients (22\%).

The immunosuppression used for induction therapy was methylprednisolone and thymoglobulin in all patients. The maintenance immunosuppression was the administration of calcineurin inhibitor in all patients, azathioprine in 4 patients (13\%), and mychophenolate in 21 patients $(65 \%)$. The major complications were 68 episodes of rejection (2.1 episodes per patient) and 61 episodes of infection (1.9 episodes per patient). No cases of tumor, diabetes mellitus, graft vascular disease, or renal failure (dialysis) were observed. Thirteen patients $(40 \%)$ developed systemic arterial hypertension. Two re-transplantations were carried out. Nine (28\%) patients died. The causes of mortality were rejection in five patients $(55 \%)$, infection in three (33\%), and multiple organ failure in one (11\%) (Figure 2). The Kaplan-Meier curve was $80 \%$ at 30 days, $70 \%$ at 1 year, and $70 \%$ at 5 years (Figure 3).

\section{Adult Heart Transplantation}

There were a total of 109 adult patients who were submitted to heart transplantation. The median age of recipients was 47 years. The median age of donors was 31 years. The immunosuppression for induction therapy was methylprednisolone in 103 patients (94.4\%), mycophenolate in 58 patients (53.2\%), azathioprine in 41 patients (37.6\%), basiliximab in six patients (5.5\%), and other drugs in seven (6.4\%) patients. The maintenance immunosuppression protocol consisted of calcineurin inhibitor in 71 patients (96\%), azathioprine in 28 (37.8\%), mychophenolate in 42 $(56.8 \%)$, and steroids in 54 (73\%). There were 43 (39.4\%) deaths. The causes of mortality were graft failure in 11 patients (26\%), multiple organ failure in $10(24 \%)$, infection 
Pediatric Heart Transplantation

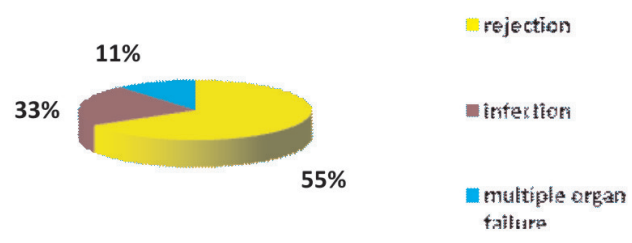

Adult Liver transplantation

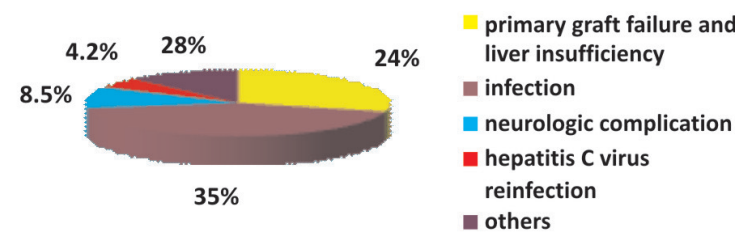

Simultaneous pancreas-kidney transplantation

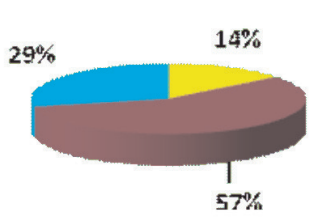

Adult heart transplantation:

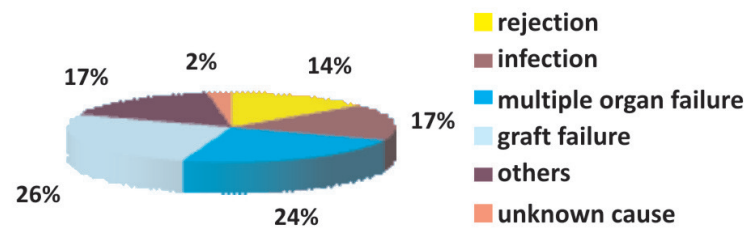

Pediatric liver tr ansplantation

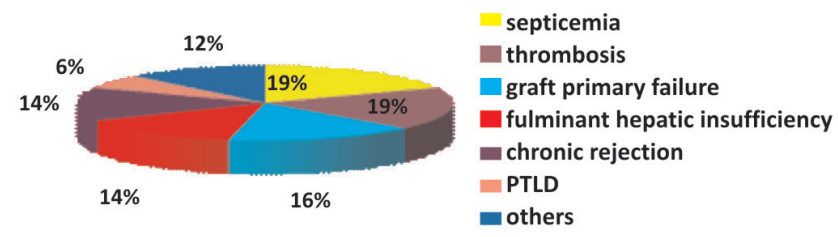

Lung transplantation

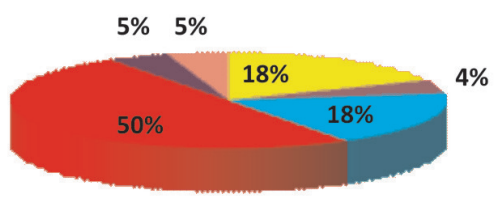

surgical complications
pulmonary thromboembolism
primary graft failure
infection
right ventricular failure
unknown cause

Adult Kidney transplantation

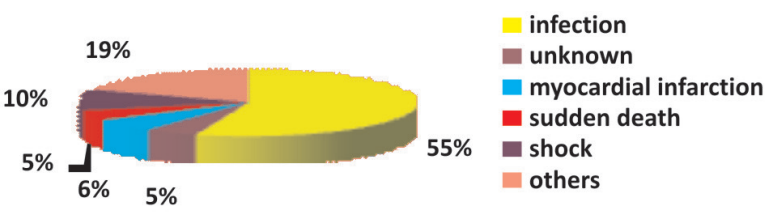

Pediatric Kidn ey transplantation

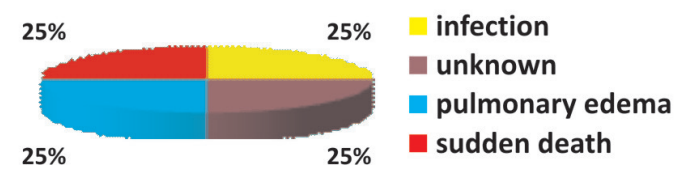

Figure 2 - Causes of mortality (2002 to 2007)

in seven (17\%), rejection in six (14\%), other causes in seven $(17 \%)$, and an unknown cause in two (2\%) (Figure 2). The Kaplan-Meier was $76 \%$ at 30 days, $64 \%$ at one year, and $56 \%$ at five years (Figure 3).

\section{Adult liver transplantation}

Two hundred and four patients received 225 liver transplants (21 were re-transplants). The median age of recipients was 47 years (range, 14 to 70 years). The
Pediatric bone marrow transplantation

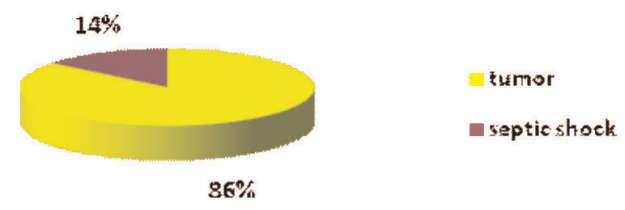

indications for liver transplantation are in table 3. Patients received immunosuppression with tacrolimus in 195 cases $(96 \%)$ or cyclosporine in $9(4 \%)$ and steroids, azathioprine in $6(3 \%)$ or mycophenolate in $32(16 \%)$. There were 71 deaths. The causes of mortality were infection in 25 patients (35\%), primary graft dysfunction in $17(24 \%)$, neurologic complication in six (8.5\%), hepatitis $\mathrm{C}$ virus reinfection in $3(4.2 \%)$, and other causes in $20(28 \%)$ (Figure 2). The Kaplan-Meier overall survival was $83.8 \%$ at 30 days, $70.2 \%$ at one year, and $66.9 \%$ at five years (Figure 3). 

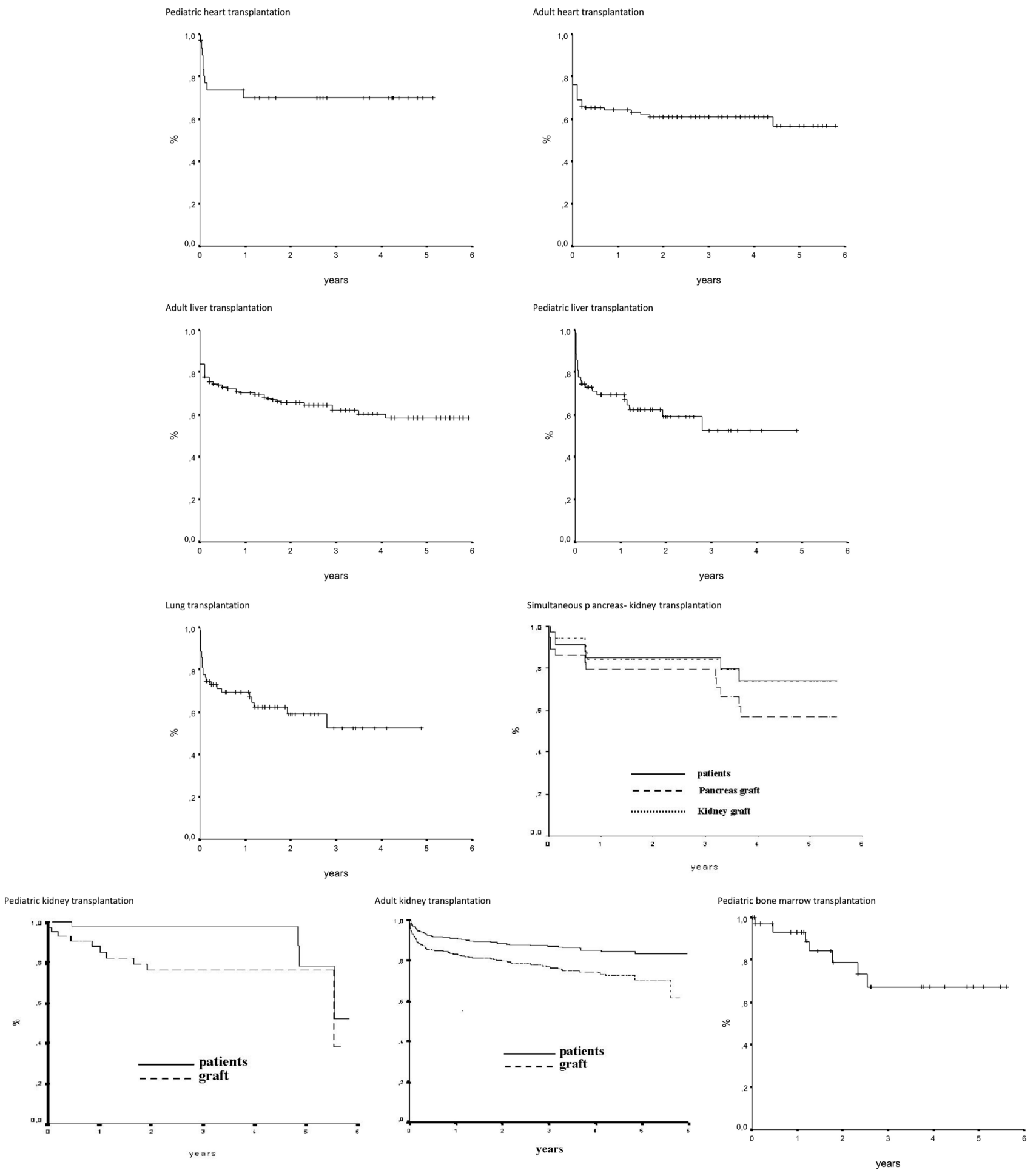

Figure 3 - Kaplan Meier survival curves - (2002 to 2007)

\section{Pediatric liver transplantation}

One hundred thirty five patients received liver transplants. The median age of recipients was 4 years (range, 7 months to 16 years). The indications for liver transplantation were biliary atresia in 75 patients (55\%), alpha-1 antitrypsin deficiency in five (4\%), fulminant hepatitis insufficiency in $13(10 \%)$, and other indications in $42(31 \%)$. The induction therapy was tacrolimus and steroids in $96(71.1 \%)$ patients, cyclosporine and steroids in $20(14.8 \%)$, and other drugs in $19(14.1 \%)$. The maintenance immunosuppression was tacrolimus in 69 patients $(80.2 \%)$, mycophenolate in 23 
Table 3 - Indications for adult liver transplantation

\begin{tabular}{lcc}
\hline Disease & $\mathrm{N}$ & $\%$ \\
\hline Hepatitis C virus & 42 & 18.7 \\
Fulminant hepatitis & 42 & 18.7 \\
Hepatocarcinoma and cirrhosis & 42 & 18.7 \\
retransplantation & 21 & 9.3 \\
Autoimmune hepatitis & 17 & 7.5 \\
Hepatitis B virus & 16 & 7.1 \\
Cryptogenic & 13 & \\
cirrhosis & 12 & 5.7 \\
Alcohol & 6 & 5.3 \\
Primary biliary cirrhosis & 2 & 2.6 \\
Primary sclerosant cholangitis & 12 & 1.0 \\
Others & 225 & 5.3 \\
\hline Total & & 100 \\
\hline
\end{tabular}

(26.7\%), steroids in 64 (74.4\%), and other treatments in 9 (10.4\%). There were 49 deaths. The causes of mortality were septicemia in nine patients (19\%), thrombosis in nine (19\%), primary graft failure in eight $(16 \%)$, fulminant hepatic insufficiency in seven (14\%), chronic rejection in seven (14\%), post-transplantation lymphoproliferative disease in three $(6 \%)$, and other causes in four (12\%) (Figure 2). The Kaplan-Meier survival curve was $84.4 \%$ at 30 days, $64.5 \%$ at one year, and $61.8 \%$ at five years (Figure 3).

\section{Lung transplantation}

Fifty-six patients received lung transplants. The median age was 47 years (range, 6 years to 67 years). There was only one child (six years old) in this group. The indications were: chronic obstructive pulmonary disease in 15 patients (27\%), fibrosis in 15 (27\%), bronchiectasis in 13 (23\%), cystic fibrosis in eight (14\%), and other indications in five (9\%). The immunosuppression for induction therapy involved methylprednisolone in 56 patients $(100 \%)$, basiliximab in 20 patients (36\%), anti-thymocyte globulin in two (4\%), and no other induction in 34 (58\%). Immunosuppression was maintained using calcineurin inhibitor in 56 patients (100\%), azathioprine in $25(45 \%)$, mycophenolate in 27 (48\%), and steroids in $56(100 \%)$. There were 22 deaths. The causes of mortality were infection in 11 patients $(52 \%)$, primary graft failure in four $(18 \%)$, surgical complications in four (18\%) patients (empyema, anastomosis dehiscence in two (8\%), and one patient (4\%) for each of the following conditions: hemoptysis and bronchovascular fistula and hemorrhage), right ventricular failure in one (4\%), pulmonary thromboembolism in one (4\%), and unknown cause in one (4\%) (Figure 2). The Kaplan-Meier survival curve was $77.7 \%$ at 30 days, $70.0 \%$ at one year, and $53.3 \%$ at five years (Figure 3).

\section{Simultaneous pancreas-kidney transplantation}

Thirty-seven patients received pancreas kidney transplants. The median age of recipients was 36 years (range, 25 years to 51 years). The indications were type I diabetes with renal chronic failure in $32(86.5 \%)$ patients, type I diabetes following kidney transplantation in three $(8.1 \%)$ patients, and type I diabetes in two $(5.4 \%)$ patients. The immunosuppression for induction therapy was: IL2R (daclizumab), tacrolimus, mycophenolate and steroids in 16 patients (43\%); and anti-thymocyte horse globulin thymoglobulin, tacrolimus, mycophenolate, and steroids in $21(56.7 \%)$. The maintenance immunosuppression in all patients was tacrolimus, mycophenolate, and steroids. There were seven deaths. The causes of mortality were cardiovascular complications in four patients (57\%), septic shock in two (29\%), and tumor in one (14\%) (Figure 2). The Kaplan-Meier overall recipient survival curve was $97.3 \%$ at 30 days, $84.9 \%$ at one year, and $74.2 \%$ at five years. The pancreatic graft survival curve was $97.3 \%$ at 30 days, $79.4 \%$ at one year, and $56.7 \%$ at five years; kidney graft survival was $97.3 \%$ at 30 days, $84.5 \%$ at one year, and $73.9 \%$ at five years (Figure 3).

\section{Kidney transplantation}

A total of 715 patients aged from 3 to 78 years (median, 41.3 years) were submitted to kidney transplantation. The indications for pediatric and adult kidney transplantation are given in Tables 4 and 5, respectively. The most common indication was chronic glomerulonephritis in 140 patients $(21 \%)$

Pediatric kidney transplantation: 50 children received kidney transplants. The median age was 13 years (range, 3 to 17 years). The immunosuppression used for induction therapy in children was basiliximab in 14 patients $(28 \%)$, daclizumab in $28(56 \%)$, and antithymocyte globulin in six $(12 \%)$. The maintenance immunosuppression was tacrolimus, mychophenolate, and steroids in 45 patients (90\%); and cyclosporine, mycophenolate, and steroids in five (10\%). Four patients died. The causes of death for the four were acute edema, sudden death, infection, and an unknown cause (Figure 2). The Kaplan-Meier graft survival curve was $95.9 \%$ at 30 days, $88.7 \%$ at one year, and $76.7 \%$ at five years. The patient survival curve was $100 \%$ at 30 days, $97.7 \%$ at one year, and $78.1 \%$ at five years (Figure 3).

Adult kidney transplantation: 665 adult patients were 
Table 4 - Indications for pediatric kidney transplantation

\begin{tabular}{lcc}
\hline Disease & N & $\%$ \\
\hline Chronic obstructive pyelonephritis & 10 & 20 \\
Nephrotic syndrome & 8 & 16 \\
Chronic glomerulonephritis & 8 & 16 \\
Hemolytic uremic syndrome & 4 & 8 \\
Renal hypoplasia & 3 & 6 \\
Unknown renal insufficiency & 3 & 6 \\
Focal segmental glomerular sclerosis & 2 & 4 \\
Congenital defect & 2 & 4 \\
Reflux nephropathy & 2 & 4 \\
Others & 8 & 16 \\
\hline Total & 50 & 100 \\
\hline
\end{tabular}

Table 5 - Indications for adult kidney transplantation

\begin{tabular}{lcc}
\hline Disease & $\mathrm{N}$ & $\%$ \\
\hline Chronic glomerulonephritis & 140 & 21 \\
Systemic arterial hypertension & 104 & 15.6 \\
Diabetes mellitus & 90 & 13.5 \\
Unknown renal insufficiency & 75 & 11.3 \\
Polycystic kidney disease & 24 & 3.6 \\
Nephrotic syndrome & 20 & 3 \\
Chronic Obstructive pyelonephritis & 18 & 2.7 \\
Lupic nephritis & 16 & 2.4 \\
Focal segmental glomerular sclerosis & 7 & 1.0 \\
Others & 171 & 25.9 \\
\hline Total & 665 & 100 \\
\hline
\end{tabular}

submitted to kidney transplantation. The median age was 45 years (range, 18 to 78 years). The induction therapy in adults was basiliximab in 306 (46\%) patients, daclizumab in 162 (24.3\%), antithymocyte globulin in 96 (14.4\%), and OKT3 in $10(1.5 \%)$ patients. The maintenance immunosuppression was tacrolimus, mychophenolate, and steroids in 497 patients (74.8\%); cyclosporine, mycophenolate, and steroids in 84 (12.7\%); cyclosporine, azathioprine and steroids in 20 (3\%); cyclosporine, rapamycin, and steroids in 16 (2.4\%); and other therapy in $48(7.1 \%)$. Eighty patients died. The causes of mortality were septic shock in 44 patients (55\%), myocardial infarction in five $(6 \%)$, sudden death in four (5\%), shock in eight (10\%), unknown causes in four (5\%), and other causes in 15 (19\%) (Figure 2). The Kaplan-Meier graft survival curve was $92.9 \%$ at 30 days, $83.2 \%$ at one year, and $70.1 \%$ at five years (Figure 3). The patient survival curve was $96.6 \%$ at 30 days, $91.0 \%$ at one year, and $83.2 \%$ at five years (Figure 3).

\section{Pediatric bone marrow transplantation}

Thirty-four patients received autologous bone marrow transplants. The median age of recipients was 6.6 years. The indications were the following: neuroblastoma in 25 patients, Ewing sarcoma in three, non-Hodgkin lymphoma in three, meduloblastoma in two, and Wilms' tumor in one. The immunosuppression for induction therapy was carboplatin (CBDCA), etoposide (ETO), and melphalan (MELFA) in 29 patients; bleomycin, etoposide, cytarabine, and melphalan (BEAM) in two; CBDCA/ETO in three; and cisplatin (CDDP), cyclophosphamide (CTX), and vincristine (VCR) in two. The number of deaths was seven. The causes of mortality were tumor in six patients $(86 \%)$ and septic shock in one (Figure 2). The Kaplan-Meier survival curve was at $96.8 \%$ at 30 days, $93.1 \%$ at one year, and $67 \%$ at five years (Figure 3).

Five children with acute myeloid leukemia (AML) and 18 children with acute lymphocytic leukemia (ALL) underwent to allogeneic bone marrow transplantation.

\section{Adult bone marrow transplantation}

A total of 728 patients underwent hematopoietic stem cell transplantation (HSCT). The indications for HSCT were multiple myeloma (173), non-Hodgkin lymphoma (169), acute myeloid leukemia (101), Hodgkin lymphoma (109), chronic myeloid leukemia (81), severe aplastic anemia (55), and acute lymphocytic leukemia (40). The indications are listed in Table 6.

The following conditioning regimens were used for the different diseases:

- non-Hodgkin lymphoma patients: BEAM - BCNU (carmustine) $300 \mathrm{mg} / \mathrm{m}^{2}+$ etoposide $\left(800 \mathrm{mg} / \mathrm{m}^{2}\right)+$ cytarabine $\left(1600 \mathrm{mg} / \mathrm{m}^{2}\right)+$ melphalan $\left(140 \mathrm{mg} / \mathrm{m}^{2}\right)$;

- multiple myeloma patients: busulfan $(12 \mathrm{mg} / \mathrm{kg})+$ melphalan $\left(100 \mathrm{mg} / \mathrm{m}^{2}\right)$ for autologous transplantation; fludarabine $\left(125 \mathrm{mg} / \mathrm{m}^{2}\right)+$ melphalan $\left(180 \mathrm{mg} / \mathrm{m}^{2}\right)$ for allogeneic transplantation;

- Hodgkin lymphoma patients: MBV - melphalan (140 $\mathrm{mg} / \mathrm{m}^{2}$ ) + BCNU (carmustine; $300 \mathrm{mg} / \mathrm{m}^{2}$ ) + VP-16 (etoposide; $2000 \mathrm{mg} / \mathrm{m}^{2}$ );

- acute myeloid leukemia patients and chronic myeloid leukemia patients: busulfan $(16 \mathrm{mg} / \mathrm{kg})+$ melphalan $(140$ $\mathrm{mg} / \mathrm{m}^{2}$ );

- severe aplastic anemia patients: busulfan $(4 \mathrm{mg} / \mathrm{kg})+$ cyclophosphamide $(200 \mathrm{mg} / \mathrm{kg})$, or total body irradiation (300 rads) + cyclophosphamide $(200 \mathrm{mg} / \mathrm{kg})$;

- acute lymphocytic leukemia patients: busulfan (16 mg/ $\mathrm{kg})+$ melphalan $\left(140 \mathrm{mg} / \mathrm{m}^{2}\right)$, or total body irradiation (1200 rads) + cyclophosphamide $(120 \mathrm{mg} / \mathrm{kg})$; 
Table 6 - Indications for adult hematopoietic stem cell transplantation

\begin{tabular}{lcc}
\hline Disease & $\mathrm{N}$ & $\%$ \\
\hline Multiple Myeloma & 173 & 23.8 \\
Non-Hodgkin Lymphoma & 169 & 23.2 \\
Hodgkin Lymphoma & 109 & 14.9 \\
Acute Myeloid Leukemia & 101 & 13.9 \\
Chronic Myeloid Leukemia & 81 & 11.1 \\
Severe Aplastic Anemia & 55 & 7.5 \\
Acute Lymphocytic Leukemia & 40 & 5.6 \\
\hline Total & 728 & 100 \\
\hline
\end{tabular}

The maintenance immunosuppression after allogeneic transplantation was cyclosporine $\mathrm{A}$ at a dose of $3 \mathrm{mg} / \mathrm{kg} /$ day (intravenous infusion), together with methotrexate at a dose of $15 \mathrm{mg} / \mathrm{m}^{2}$ ) on day +1 and a dose of $10 \mathrm{mg} / \mathrm{m}^{2}$ on days +3 , +6 , and, +11 after HSCT.

\section{Bone transplantation}

A total of 1167 patients received bone, ligament, or tendon transplants. The median age of recipients was 48 years (range, 2 to 90 years). The indications for transplantation were either odontologic (813 patients, $69.7 \%$ ) or orthopedic (354 patients, 30.3\%). Odontological indications of bone transplantation were mandibular and maxilar bone loss caused by tumors, trauma, and periodontal disease. Orthopedic indications were divided into the following groups: hip surgery $(177,50 \%)$, knee surgery $(128,36 \%)$, tumor surgery $(35,10 \%)$, and shoulder surgery $(14,4 \%)$. The main indication for hip surgery was revision hip arthoplasty with femoral or acetabular bone loss. Bone and ligament transplantation in knee surgery was used in revision knee arthoplasty, reconstruction of anterior cruciate ligament injury, (patellar graft, semitendinosus and gracilis graft), and severe trauma. The indications for the tumor group were benign lesions (unicameral and aneurismal bone cysts, non-osteogenic fibromas), and malignant tumors (Ewing sarcoma and osteosarcoma). Indications for shoulder surgery were repair of rotator cuff injuries and acromioclavicular dislocations using ligaments and rotator cuff grafts. Immunosuppression was not used for induction or maintenance therapy, since bone, ligament, and tendon transplantation, unlike transplantation of other solid organs, do not cause death in the event of graft failure. The main complications of bone transplantation were infection and immunogenic reaction against the graft. Of 35 patients in the tumor group, two (5.7\%) developed infection, two (5.7\%) had immunogenic reactions, three $(8.6 \%)$ had allograft fractures that required revision and autologous bone grafts, and one $(2.9 \%)$ had recurrence of the tumor in the leg that had received the transplantation, and the leg was therefore amputated.

\section{Skin transplantation}

Eighty-one patients aged 0.3 years to 78 years (median, 34 years) received skin transplants. The main use of this transplantation was for temporary skin coverage until an autogenous graft could be implanted. The indications for skin transplantation were large burns with few skin donor areas in 38 patients $(46.9 \%)$, wound bed preparation in $28(34.5 \%)$, hemodynamic instability in seven $(8.6 \%)$, pyoderma gangrenosum in four $(4.9 \%)$, aplasia cutis in two (2.4\%), and giant congenital nevi in two (2.4\%). After 3-5 days, the allogeneic skin was removed and the wound bed was evaluated. If there was sufficient granulation tissue then an autogenous graft was made; if the granulation tissue was not good, a new transplantation was performed. In this way, 22 patients received a re-transplantation for wound bed preparation. The mortality rate of the patients was $16.4 \%$ : 13 patients died, five in the group of hemodynamic instability and eight in the group of large burns with few donor skin sites.

\section{COMMENTS AND DISCUSSION}

The total number of solid organ transplant procedures (38.7\%) of all transplants remained unchanged during the period (range, 2002 to 2007). The number of tissue transplants increased during the last two years, especially bone transplants.

Immunosuppression: The most common combinations of therapies included calcineurin inhibitor and mycophenolate. A smaller percent of patients were taking a calcineurin inhibitor combined with azathioprine.

Outcomes: Overall survival at 30 days, one year, and five years shows that the results of our institution ${ }^{6-21}$ are compatible with previously reported data. ${ }^{22-26}$ Infection and rejection were the main causes of death in the majority of the organ transplants in our report. This indicates that these two complications remain a challenge for physicians who take care of organ transplant patients.

We will continue to update our experience in an attempt to describe what is presently occurring in organ transplantation in our institution.

\section{CONCLUSION}

This is the initial registry report from our institution. It 
will help us define baseline data that will form the basis of comparison for our future reports. This report shows that solid organ and tissue transplantations are feasible within the institution and they allow us to expect that the quality of results will improve in the future.

\section{APPENDIX}

The members of the Solid Organ and Tissue
Transplantation Committee of Hospital das Clínicas of University of São Paulo Medical School were as follows: Estela Azeka, José Otavio Costa Auler Júnior, Paulo Manuel Pego Fernandes, Willian Carlos Nahas, Alfredo Inácio Fiorelli, Uenis Tannuri, Lílian Maria Cristofani, Marcelo Tadeu Caiero, Frederico Luiz Dulley, André de Oliveira Paggiaro, Telesforo Bacchella. José Otavio Costa Auler Jr. was also the clinical director of the Hospital das Clínicas of University of São Paulo Medical School.

\section{REFERENCES}

1. Barbosa ND, Azeka E, Aiello VD, Viana F, Jatene M, Tanamati C, et al Isolated left ventricular noncompaction: unusual cause of decompensated heart failure and indication of heart transplantation in the early infancycase report and literature review. Clinics. 2008;63:136-9.

2. Samano MN, Minamoto H, Oliveira EQ, Caramori ML, Pêgo-Fernandes $\mathrm{PM}$, Jatene F. Bronchial stenosis treatment after lung transplantation with a self-expandable silicone stent. Clinics. 2007;62:643-4.

3. Lucon AM, Coelho RF, Chambô JL, Mitre AI, Praxedes JN, Srougi M. Hand-assisted laparoscopic right nephrectomy and autotransplantation for treatment of renovascular hypertension. Clinics. 2007;62:367-70.

4. Filho JA, Machado MA, Nani RS, Rocha JP, Figueira ER, Bacchella T, et al. Hypertonic saline solution increases cerebral perfusion pressure during clinical orthotopic liver transplantation for fulminant hepatic failure: preliminary results. Clinics. 2006;61:231-8.

5. Rocha-E-Silva R, de Pádua Mansur A, Fabri Junior J, Ramos RB, Cunha Filho CE, Dallan LA, et al. Coronary revascularization with the left internal thoracic artery and radial artery: comparison of short-term clinical evolution between elective and emergency surgery. Clinics. 2005;60:227-32.

6. Azeka E, Marcial MB, Jatene M, Auler JO, Ramires JA. Eight-year experience of pediatric heart transplantation: clinical outcome using non-invasive methods for the evaluation of acute rejection. Pediatr Transplant. 2002;6:208-13.

7. Azeka E, Auler JO, Marcial MB, Fumagalli F, Ramires JA. Heart transplantation in children: clinical outcome during the early postoperative period. Pediatr Transplant. 2005;9:491-7.

8. Azeka E, Franchini Ramires JA, Valler C, Alcides Bocchi E. Delisting of infants and children from the heart transplantation waiting list after carvedilol treatment. J Am Coll Cardiol. 2002;40:2034-8.

9. Abdala E, Gotardo DRM, Bonazzi PR, Bacchella T. Hepatitis C treatment before and after liver transplant. The Brazilian Journal of infectious Diseases. 2007;11:61-5.

10. Bacchella T, Machado MCC. The first clinical liver transplantation of Brazil revisited. Transplant Proc. 2004;36:929-30.

11. Bacchella T, Galvao FHF, Almeida JLJ, Figueira ER, Moraes A, Machado MCC. Marginal grafts increase early mortality in liver transplantation. Sao Paulo Med J. 2008; 126:161-5.

12. Abdala E, Bacchella T, Machado MCC. Seleção, avaliação e preparo de receptores hepáticos adultos. In: Garcia VD, Abbud Filho M, Neumann J, Medina Pestana J, Eds. Transplante de órgãos e tecidos. 2ed São Paulo: Segmento Farma, 2006

13. Meirelles Jr R, Bacchella T, Cocuzza C, Makdissi F, Rocha-Santos V, David-Neto E, et al. Simultaneous pâncreas-kidney transplantation: a tem year follow-up analysis from Clinical Hospital of Medical School of University of São Paulo, Brazil. Transplantation 2008; 86 (2S) (abstract in press).
14. Fiorelli AI, Stolf NA, Honorato R, Bocchi E, Bacal F, Uip D, et al. Late evolution after cardiac transplantation in Chagas' disease. Transplant Proc. 2005;37:2793-8.

15. Auler Junior JO, Carmona MJ, Bocchi E, Bacal F, Fiorelli AI, Stolf N, et al. Low doses of inhaled nitric oxide in heart transplant recipients. $\mathrm{J}$ Heart Lung Transplant 1996; 15:443-50.

16. Bocchi EA, Bacal F, Auler Junior JO, Carmone MJ, Bellotti G, Pileggi F. Inhaled nitric oxide leading to pulmonary edema in stable heart failure. Am J Cardiol. 1994;74:70-2.

17. Nahas WC, Antonopoulos IM, Piovesan AC, Pereira LM, Kanashiro H, David-Neto E, et al. Comparison of renal transplantation outcomes in children with and without bladder dysfunction. J Urol. 2008;179:7126.

18. Tannuri U, Velhote MC, Santos MM, Gibelli NE, Ayoub AA, MaksoudFilho JG, et al. Pediatric liver transplantation: fourteen years of experience at children institute in Sao Paulo, Brazil. Transplant Proc. 2004:36:941-2.

19. Odone Filho V. Transplante autólogos de medula óssea em oncologia pediátrica - experiência preliminar do Instituto da Criança Prof. Pedro de Alcantara do Hospital das Clínicas da Faculdade de Medicina da Universidade de Sao Paulo. Jornal de Pediatria. 1996;72:209-14.

20. Samano MN, Waisberg DR, Villger, Pego-Fernandes PM, Jatene FB. Bilateral lung transplantation in asymmetric thorax: case report. Transplant Proc. 2008;40:872-4.

21. Dulley FL, Vigorito AC, Aranha FJ, Sturaro D, Ruiz MA, Saboya R, et al. Addition of low -dose busulfan to cyclophosphamide in aplastic anemia patients prior to allogeneic bone marrow transplantation to reduce rejection. Bone Marrow Transplant. 2004;33:9-13.

22. Kaneku HK, Terasaki PI. Thirty year trend in kidney transplants: UCLA and UNOS Renal transplant registry. Clin Transpl. 2006;1:1-27.

23. Cai J. Thoracic transplantation in the United States: an analysis of UNOS registry data. Clin Transpl. 2006;1:41-56.

24. Waki K. UNOS Liver Registry: ten year survival. Clin Transpl. 2006;1:29-39.

25. Boucek MM, Aurora P, Edwards LB, Taylor DO, Trulock EP, Christie $\mathrm{J}$, et al. Registry of the International Society for Heart and Lung transplantation: tenth official pediatric heart transplantation report- 2007. J Heart Lung Transplant. 2007;26:796-807.

26. Miano M, Labopin M, Hartmann O, Angelucci E, Cornish J, Gluckman E, et al. Haematopoietic stem cell transplantation trends in children over the last three decades: a survey by the paediatric diseases working party of the European Group for Blood and Marrow Transplantation. Bone Marrow Transplantation. 2007;39:89-99. 